\author{
Petryk Oleh \\ People's Artist of Ukraine, Ballet Soloist of the \\ Lviv National Academic Opera and \\ Ballet Theatre named after Solomiia Krushelnytska, \\ Professor of the Department of Stage Production \\ and Choreography of the \\ Lviv Ivan Franko National University \\ ORCID 0000-0002-4245-3839 \\ art.ua.Iviv@gmail.com
}

\title{
POLYASPECTNESS OF CREATIVITY OF SERHII NAIENKO
}

Purpose of Research is to recreate the whole panorama of creativity of Serhii Naienko. Methodology. Application of a set of methods (analysis and synthesis, induction and deduction, chronological, art study analysis) allowed to reveal the main components of the creative way S. Naienko. Scientific novelty. For the first time, a complete panorama of performance, choreography, and pedagogical creativity of Serhii Naienko was reproduced. Conclusions. For many decades, the basis of productive creative activity of S. Naienko was studying at the Leningrad State Choreographic School named after Agrippina Vaganova, the leading educational institution in the world for the preparation of ballet actors. The main components of Naienko's creative way in Lviv were: the performance of leading ballet parties of a wide genre range in the Lviv Opera and Ballet Theater; acquiring actor and choreographer experience in dramatic performances at the city's theaters; the formation of ballet master's skill in parallel with the performing career under the influence of domestic (G. Isupov, A. Shekera etc.) and Russian (M. Dolgushin etc.) choreography schools; production of classical ballets and original works; choreographer's quest for expanding the lexical range of performances (a combination of classical dance, modern dance elements, characteristic dance, free plastic etc.); creating a large number of dance scenes in operas; a combination of choreographer's activities with a pedagogical at the Lviv State Choreographic School, the Lviv School of Culture and Arts, at the Department of Directing and Choreography at the Ivan Franko National University of Lviv.

Key words: Naienko Serhii; Lviv Opera and Ballet Theater; ballet actor; choreographer.

Петрик Олег Олегович, народний артист України, соліст балету Львівського національного академічного театру опери і балету імені Соломії Крушельницької, професор кафедри режисури та хореографії Львівського національного університету імені Івана Франка

Поліаспектність творчості Сергія Наєнка

Мета дослідження - відтворити цілісну панораму творчості Сергія Наєнка. Методологія. Застосування комплексу методів (аналіз та синтез, індукція та дедукція, хронологічний, мистецтвознавчий аналіз) дозволило виявити основні складові творчого шляху С. Наєнка. Наукова новизна. Вперше відтворено цілісну панораму виконавської, балетмейстерської, педагогічної творчості Сергія Наєнка. Висновки. Фундаментом продуктивної творчої діяльності С. Наєнка упродовж багатьох десятиліть стало навчання в Ленінградському державному хореографічному училищі імені Агрипини Ваганової - провідному навчальному закладу в світі з підготовки артистів балету. Основними складовими творчого шляху С. Наєнка у Львові стали: виконання провідних балетних партій широкого жанрового діапазону у Львівському оперно-балетному театрі; набуття акторського та балетмейстерського досвіду в драматичних виставах у театрах міста; формування балетмейстерської майстерності паралельно 3 виконавською кар'єрою під впливом вітчизняної (Г. Ісупова, А. Шекери тощо) та російської (М. Долгушин тощо) балетмейстерських шкіл; постановка редакцій класичних балетів та оригінальних авторських творів; балетмейстерські пошуки по розширенню лексичного діапазону вистав (поєднання класичного танцю, елементів танцю модерн, характерного танцю, вільної пластика тощо); створення великої кількості танцювальних сцен в операх; поєднання балетмейстерської діяльності з педагогічною у Львівській державній хореографічній школі, Львівському училищі культури і мистецтв, на кафедрі режисури та хореографії Львівського національного університету імені Івана Франка.

Ключові слова: Наєнко Сергій; Львівський театр опери та балету; артист балету; балетмейстер.

Петрик Олег Олегович, народный артист Украины, солист балета Львовского национального академического театра оперы и балета имени Соломии Крушельницкой, профрессор кафедры режиссуры и хореографии Львовского национального университета имени Ивана Франко

\section{Полиаспектность творчества Сергея Наенко}

Цель исследования - воссоздать целостную панораму творчества Сергея Наенко. Методология. Применение комплекса методов (анализ и синтез, индукция и дедукция, хронологический, искусствоведческий анализ) позволило выявить основные составляющие творческого пути С. Наенко. Научная новизна. Впервые воспроизведена целостная панорама исполнительского, балетмейстерского, педагогического творчества Сергея Наенко. Выводы. Фундаментом продуктивной творческой деятельности С. Наенко на протяжении многих десятилетий стало обучение в Ленинградском государственном хореографическом училище имени Агриппины Вагановой - ведущем учебном заведении в мире по подготовке артистов балета. Основными составляющими творческого пути С. Наенко во Львове стали: выполнение ведущих балетных партий широкого жанрового диапазона во Львовском оперно-балетном театре; приобретения актерского и балетмейстерского опыта в драматических спектаклях в театрах города; формирование балетмейстерского мастерства параллельно с исполнительской карьерой под влиянием отечественной (Г. Исупова, А. Шекеры и т.д.) и российской (М. Долгушин и т.д.) балетмейстерских школ; постановка редакций классических балетов и оригинальных авторских произведений; балетмейстерские поиски по расширению лексического диапазона спектаклей (сочетание классического танца, элементов танца модерн, характерного танца, свободной пластика и т.п.); создание большого количества танцевальных сцен в операх; сочетание балетмейстерской деятельности с педагогической во Львовской государственной хореографической школе, Львовском училище культуры и искусств, на кафедре режиссуры и хореографии Львовского национального университета имени Ивана Франко.

Ключевые слова: Наенко Сергей; Львовский театр оперы и балета; артист балета; балетмейстер.

Actuality of Research. The reproduction of a comprehensive panorama of the development of the Ukrainian ballet theatre is one of the most important tasks of contemporary art studies. It can only achieved by the multidimensional studies, devoted to performers and choreographers, who took part in the development of the national ballet in various opera and ballet theatres. The personal plan of the ballet actors and

\footnotetext{
${ }^{\odot}$ Petryk O., 2019
} 
choreographers of the Lviv National Academic Theatre of Opera and Ballet after Solomiya Krushelnytska is rather little researched problems. The creativity of Sergei Nyanenko, the Honoured Artist of Ukraine, a choreographer-director, has been fragmentarily under the scientific reflection.

Analysis of Research and Publications. There is a special scientific work by A. Tereshchenko [10], which devoted to the Lviv Opera and Ballet Theater does not highlight the work of S. Naenko because it was published in 1989. In his fundamental work, Yu. Stanishevskyi, mentioned S. Naenko as an actor of the Lviv theatre among others $[9,372]$. Some aspects of the ballet development in the Lviv Opera and Ballet Theatre of the late XX - early XXI centuries were analysed in the work of O. Palamarchuk [6], who noted the prospects of $\mathrm{S}$. Naenko ballet mastery. The publications in the periodical press, devoted to the premiere shows of S. Nyanko ballets (G. Kanarska [1; 2], Yu. Chekan [12], etc.) are very important for our further studies. However, there is no any comprehensive researches of $S$. Nanenko creativity and works.

The purpose of the research is to recreate the whole panorama of Sergey Naienko creativity.

Main part. Sergey Niaenko has been working as a ballet dancer and choreographer in Lviv for thirty years. The formation of professional mastery began from his education. In 1985, Sergii Naienko graduated the Leningrad State Choreographic School after Agrippina Vaganova, which was one of the most famous institutions of choreographic education in the USSR [8]. At the school, his teachers were Natalia Sakhnovska and Robert Herbeck, who were one of the most famous in the USSR ballet dancers of the Leningrad Opera and Ballet Theatre after S. M. Kirov.

S. Naienko told enthusiastically about the creative atmosphere of the Lviv theatre: «l thank God for getting to the theatre of Eugen Lysyk. I was in space, in the wonderful worlds, created by him ... Moreover, it did not matter my parties in his performances: whether in "Spartacus», «Medea», or "Esmeralda». For me, my emotional exciting from the playing on the stage was the most important. There were a magic, a great magic of arts, created by people generously endowed with divine gift. At that time, I understood little, whereas my desire to master or get closer to that creative impulse, to know the nature of its source, helped me to form my professional skills. With a clear choreography, there was the free ballet plaster, built on soft transitions» [5].

Some time passed, S. Naienko began performing the leading parties of the most theatre repertoire ballets. He was a talented artist with a wide genre range. He played the following ballet parties: Rothbart in «Swan Lake» by P. Tchaikovsky, Hans in «Giselle» by A. Adam, Tibald in «Romeo and Juliet» by S. Prokofiev, God in «Creation of the World» by A. Petrov, Fakir Magadavea and Hindu dance (solo) at «La Bayaderca» by L. Minkus, Prince and Pervo at «Lilia» K. Dankevych, Drosselmeyer in «Nutcracker» by P. Tchaikovsky, Eskamillo and Fatum at «Carmen Suite» by G. Bizet, and R. Shchedrin, Don Quixote and Hammock in «Don Quixote» by L. Minkus, etc. [8].

The academic ballet scene was too small for him. So, S. Naienko wanted to experiment in ballet as well as in dramatic theatres. The Theatre «Room No. 089», created together with director Vadim Sidletsky was the platform where S. Naienko tried himself as a dramatic actor. In addition, S. Naienko collaborated with the Theatre "Gaudeamus», headed Boris Ozerov, and participated in the performances of other Lviv theatres [2].

In addition to self-realization as a drama actor, S. Naienko worked on the plastic design of dramatic performances in many Lviv theatres. S. Naienko collaborates with the Polish Folk Theatre and Z.Khshanovskyi, its director, helping to find figurative and plastic solutions of the dramatic performances [2].

At the turn of the centuries, S. Naienko is active as a choreographer. O. Palamarchuk highly appreciated the work of $\mathrm{S}$. Naienko as a director, noting that, being a soloist, he was in success «in his own performances ... As the director created his own ballets, which attracted the audience attention by the choice of non-standard themes and the unordinary choreographic lexica» [6, 340].

Sergii's works were based on a deep analysis of the works of the choreographers - Nikita Dolgushyn, Semen Drechyn, who periodically staged performances in Lviv. S. Naienko also analysed the achievements of the national choreography school - G. Isupov, A. Shekera and others.

O. Petryk, the People's Artist of Ukraine stated that S. Naienko had demonstrated the outstanding abilities at the beginning of his choreography career. «Lviv got simply lucky with S. Naienko, a very talented person. In addition, being a great ballet actor, he seemed to have the internal sensation of a stage ... That choreographer understood the movements and gestures in correspondence with flows of music. Our director has never worked himself, whereas he has been working with the actors. This is the very creative and lively collaboration when you see how the choreographer creating the plot of the future performance according to music» [4]. The ballet master's method of S. Naienko became the close cooperation with the performers, which contributed to the organic nature of the parties, created taking into account technical, dance and actor's skills of the artists.

S. Naienko is the author of the one-act ballet «Music on the Water, or the Wedding of Neptune» on the suite of G. F. Teleman; the choreographic sonnets for B. Britten's «Simple Symphony». The opera inspired him to create the ballet «Bel canto» on the music of the famous opera arias, which were performed on stage of the Lviv Theological theatre «Resurrection». In addition, the opera arias became the musical basis of the performance «Double Nonsense», where the arias were combined with the light jazz. These performances were the forerunners of the ballet, dedicated to the opera singer. 
The ballet «Madam Butterfly's Return» is characterized by the extraordinary artistic originality. Its music was written by M. Skoryk. The performance was devoted to Solomiya Krushelnytska. Her beautiful voice of the singer was embodied in a dance. The ballet performance had the features of the great opera, every life event of S. Krushelnytska was reproduced in the play with «the most subtle psychological nuances» [2]. The choreographer focused on the complicated psychological collisions of the image of Solomia Krushelnytska - her endless love to art, her relationship with Niusya, her younger sister and her creative friendship with Giacomo Puccini. The ballet dancer involved to the performance the whole troupe. Myroslav Skoryk's music was organically combined with Puccini's music.

The main idea of the ballet "Little Prince» was the relationship between the creator and his works. The choreographer put in practice his desire to highlight the idea of creating a composition.

The ballet «The Night of Federico Garcia Lorca», by A. Sirenko was staged by S. Naienko and became a kind of plastic choreographic transcription of the poetry. The ballet master used many elements of dance-modern and the stylistic features of the Andalusian dance folklore dance - flamenco.

Today, «Carmen Suite» by G. Bizet and R. Shchedrin, staged by S. Naienko is the popular performance of the repertoire of the Lviv Opera Theatre. The choreographer has been working on the ballet since the 1990's. There was its premiere in 2007. The image of Carmen got the new interpretation as a teenage girl in spite of the popular concept of the woman of vamp.

In 2017, S. Naienko staged the original performance of «Man, or Mystery of Master Pinsel», written by Yu. Laniuk. Its demonstration was held in the Mirror Hall of the Opera within the Music Festival «Yuriy Laniuk and his Friends» [2]. The dancer told the story about the famous sculptor of the Baroque era, whose work became a history of Lviv as well as Galicia.

$\mathrm{S}$. Naienko staged a choreography of the second act of the monumental performance «When the Fern is Blooming» on the music of Yevhen Stankovych. It impressed Ukraine in 2018 (the first part was staged by A. Shoshin). The choreographer illustrated the humanitarian catastrophe, war, chaos in Ukraine from the Cossack times to the present. Yu. Chekan, a well-known critic, analysing the performance, tells about the directing reception of the opposition between the choir and the ballet - «a static choir-commentator and a dynamic active ballet» [12].

In March 2018, to his 30th anniversary of the creative activity, S. Naienko created the ballet "Love is a Sorceress», which consisted of three one-act ballets: «The Fragments» V.-A. Mozart, «Hamlet» to the music of the eponymous overture-fantasy by P. Tchaikovsky (edited by M. Dolgushin), «Love is a Sorceress» by Manuel de Falla. In fact, the first ballet was the jubilee because the dancer played the part of Salieri [7].

In addition, there are many dance scenes in operas among S. Naienko ballet performances. In 2001, the premier of the opera «Moses», by M. Skoryk was the great artistic event in Lviv as well as in Ukraine. The Success of the play was the outstanding ballet, directed by S. Naienko [6, 338]. In general we can see the choreography of $S$. Naienko in the following operas: «Aida» by D. Verdi, «Orpheus and Eurydice» by C.W. Gluck, «The Magic Flute» by V.-A. Mozart, «Carmen» by G. Bizet, «Don Pasquale» by G. Donizetti, operetta «Gypsy Baron» by J. Strauss. All of them are included in the repertoire of the Lviv National Opera.

The choreographer provided the significant work in K. Orff's opera "Carmina Burana», created in 2011. It got a great success during the a tour of the cities of France. The plastic palette of S. Naienko enhanced the content of poetry and depth of music. The choreographer introduced many elements of Ukrainian dance. Anastasia Isupova, a soloist of the ballet, believes that «the most modern choreography» of «Carmina Burana» impresses the European audience and attracts their attention. In her opinion, the future of the theatre is precisely the contemporary vision of the work, which requires the understanding of the world of opera and ballet [11].

Sergii Naienko has been teaching at the Lviv State Choreographic School since 1990. At that period he staged more than three hundred original choreographic miniatures and one-act ballets «Flow of Time» (music of «Morning Serenade» by F. Pulenko), «Seasons» by O. Glazunov, and the original the version of «Nutcracker» by P. Tchaikovsky, the original version of «Aubade» by F. Pulenko for the graduate performance of the Lviv State Choreographic School. In 2011, he opened the Children's Ballet Theatre at the school where S. Nayenko staged «Mykyta Fox» by I. Vymer. His students participated in the VIII International Ballet Performances Festival «Gran-Pa» in Donetsk [3, 206].

Working in the theatre, S. Naienko gives the courses of the lectures Lviv State Choreographic School, Lviv college of Culture and Arts and at the Department of Directing and Choreography in Ivan Franko National University of Lviv.

Scientific Novelty. For the first time, the directing, choreographic and pedagogical creativity of Sergii Naienko was analysed.

Conclusions. Thus, the basis of productive creative activity of S. Nayenko was his education at the Leningrad State Choreographic School after Agrippina Vaganova, the leading educational institution in the world for the preparation of ballet actors.

The main components of N. Naienko's creative way in Lviv are the performance of the leading ballet parties of a wide genre range in the Lviv Opera and Ballet Theatre; the gaining of the actor and choreographer experience in the dramatic performances at the city's theatres; the formation of the ballet master's skill in parallel with the performing career under the influence of domestic (G. Isupov, A. Shekera, etc.) and Rus- 
sian (M. Dolgushin, etc.) choreography schools; the directing of classical ballets and original works; the choreographer's seeking for the new lexical range of performances (a combination of classical dance, modern dance elements, characteristic dance, free plastic, etc.); creating a number of dance scenes in operas; the combination of choreographer's activities with the pedagogical carrier at the Lviv State Choreographic School, the Lviv college of Culture and Arts and at the Department of Directing and Choreography at the Ivan Franko National University of Lviv.

\section{תimepamypa}

1. Канарська Г. Папороть знайшли, але... Збруч. 2017. 20 грудня. URL : https://zbruc.eu/node/74615 (дата звернення: 23.12.2018).

2. Канарська Г. Сергій Наєнко: іронічний уклін. Збруч. 2018. 16 серпня. URL : https://zbruc.eu/node/82350 (дата звернення: 18.12.2018)

3. Мокрій Р. Становлення Львівської державної хореографічної школи. Вісник львівського університету. Серія мистецтвознавство. 2015. Вип. 16, Ч. 1. С. 203-208. (дата звернення: 20.12.2018).

4. Наєнко - розкіш, яку варто цінувати. Postup - Поступ. 2001. №60(718), 20 квітня. URL: http://postup.brama.com/010420/60_7_2.html (дата звернення: 21.12.2018).

C. 31 .

5. Наєнко С. «Мені завжди подобались виконавці, які могли наповнити форму...». Театральна бесіда. 1998 . № 2.

6. Паламарчук О. Музичні вистави Львівських театрів (1776 - 2001). Львів, 2007. 449 с.

7. Прем'єра до 30 річчя діяльності! Львівський оперний запрошує на вечір одноактних балетів «Любов-чарівниця». Lvivpost.net. 2018. №21(2033), 17 березня. URL : http://www.Ivivpost.net/kultura/n/42039 (дата звернення: 22.12.2018).

8. Сергій Наєнко. Львівська національна опера. URL : https://opera.lviv.ua/personel/sergij-nayenko/ (дата звернення: 21.12.2018) (дата звернення: 21.12.2018).

9. Станішевський Ю. Балетний театр України : 225 років історії. Київ, 2003. 438 с.

10. Терещенко А. Львівський театр опери та балету імені Івана Франка: піввіковий творчий шлях. Київ : Музична Україна, 1989. 208 с.

11. Терещук Г. «Любов до опери потрібно виховувати» - французький диригент Григорій Пентелейчук. Радіо Свобода. 2011. 20 грудня. URL : https://www.radiosvoboda.org/a/24428432.html (дата звернення: 18.12.2018).

12. Чекан Ю. П'ять поглядів на «Цвіт папороті». Moderato.in.ua 2018. 8 січня. URL: https://moderato.in.ua/events/p-yatpoglyadiv-na-tsvit-paporoti.html (дата звернення: 21.12.2018).

\section{References}

1. Kanarska, H. (2017, December 20) Fern found, but ... Zbruch. Retrieved from https://zbruc.eu/node/74615 [in Ukrainian]. Ukrainian].

2. Kanarska, H. (2018, August 16). Serhii Naienko: ironic bow. Zbruch. Retrieved from https://zbruc.eu/node/82350 [in

3. Mokrii, R. (2015). Formation of the Lviv State Choreographic School. Visnyk of Lviv University. Series Art Studies, issue 16, part 1, 203-208 [in Ukrainian].

4. Naienko - luxury to be appreciated. (2001, April 20). Postup - Postup. Retrieved from http://postup.brama.com/010420/60_7_2.html [in Ukrainian].

5. Naienko, S.(1998). «I always liked the performers who could fill the form ...». Teatralna besida, issue 2, 31 [in Ukrainian].

6. Palamarchuk, O. (2007). Musical performances of Lviv theaters (1776-2001). Lviv [in Ukrainian].

7. Premiere to the 30th anniversary of activity! Lviv opera invites to the evening of one-act ballets "Love-witch". (2018, March 17). Lvivpost.net. Retrieved from http://www.lvivpost.net/kultura/n/42039 [in Ukrainian].

8. Serhii Naienko. (2018). Lviv National Opera. Retrieved from https://opera.Iviv.ua/personel/sergij-nayenko/ [in Ukrainian].

9. Stanishevskyi, Yu. (2003). The ballet theatre of Ukraine: 225 years of history. Kyiv: Muzychna Ukraina [in Ukrainian].

10. Tereshchenko, A. (1989). The Lviv Opera and Ballet Theater named after Ivan Franko: The half-century creative way. Kyiv: Muzychna Ukraina [in Ukrainian].

11. Tereshchuk, H. (2011, December 20). "The love for the opera must be brought up"- French conductor Hryhorii Penteleichuk. Radio Liberty. Retrieved from https://www.radiosvoboda.org/a/24428432.html [in Ukrainian].

12. Chekan, Yu. (2018, January 8). Five looks at "Fern Flower". Moderato.in.ua Retrieved from https://moderato.in.ua/events/p-yat-poglyadiv-na-tsvit-paporoti.html [in Ukrainian]. 